open $\odot$ access

\title{
Case Report: The Excessive Fear and Dysfunctional Anxiety about the Coronavirus Disease-19: A Case Report in a Male with Coronaphobia
}

\author{
Heni Indrawati Dalimunthe*(D), Elmeida Effendy (D), Mustafa M. Amin (D) \\ Department of Psychiatry, Faculty of Medicine, Universitas Sumatera Utara, Medan, Indonesia
}

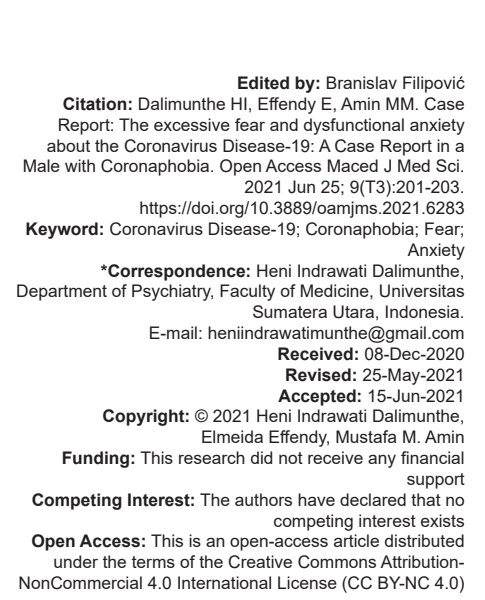

\section{Abstract}

BACKGROUND: The coronavirus disease (COVID-19) pandemic has been well acknowledged dominated headlines throughout the world. During a pandemic, fear related to COVID-19 is a natural psychological reaction, expressed not only in fear and anxiety related to disease and death, but also correlated with occupational social stress. A different type of developmental event, the emergence of a particular phobia, may be signaled when these fears persist and become more severe. A recent emerging phobia unique to COVID-19 is coronaphobia.

CASE REPORT: We presented a case of coronaphobia in a 24-year-old male social and political sciences student in his past year academy at local community college, unmarried, from Melayu tribe. He came with his sister to seek treatment from a psychiatrist for his excessive fear and dysfunctional anxiety about the COVID-19.

CONCLUSION: We give psychoeducation to him, recognizing the diagnosis, describing the process of learning fea and how it was sustained. Therapy concentrated on giving him potential reasons to challenge his doubts, patterns of avoidance, and efforts were made to replace it with more adaptive values and answers.

\section{Introduction}

In February 2020, the World Health Organization (WHO) formally designated the disease caused by the novel coronavirus as coronavirus disease 2019 (COVID-19). This was first recorded at the end of 2019 from the city of Wuhan, China. In the following weeks, a new pandemic is spreading diseases through China and other countries across the world [1]. The 2019 COVID-19 pandemic is an ongoing major global health epidemic in 220 countries and territories, with 53,766,728 confirmed COVID-19 cases and 1,308,975 fatalities from December 2019 until the time of writing this article. Indonesia was also seriously affected by the infection of COVID-19. By November 15, 2020, 467,113 confirmed COVID19 cases were registered in Indonesia and 15,211 disease-related deaths resulted in self-quarantine and social distancing [2]. A study from China investigated that COVID-19 is linked to depression that accounts for $17-48 \%$ of population and $23-28 \%$ was found to experience anxiety disorder from which $4 \%$ appeared to be from university students population [3]. Another research result is that when considering other sociodemographics, COVID-19 variables, and other fear variables, men are twice as likely to experience depression as women. Given the previous studies that found women were almost twice as likely as men to suffer from depression, this result is unexpected [4].

Fear is one factor which seems to contribute to this trend of pandemic psychopathology. Experiencing fear and anxiety during a pandemic is a normal psychological reaction, even as adaptive and remarkable markers of increasingly complex reasoning and abstract thought processes can be seen. When these fears persist and become more serious, a particular phobia develops [5], [6]. The following are the risk factors leading to coronaphobia: An unforeseen truth, endless uncertainties, the need to learn new practices and avoidance behavior, lack of confidence in health infrastructure, the contraction of COVID-19 by heads of states, cautionary statements by international organizations, and the incessant infodemic taking the form of an infodemic. Coronaphobia is created by the interaction of external triggers that act as risk factors with the psychosocial mechanisms of routine life intervention, disastrous interpretations, and social risk amplification [4]. 


\section{Case Report}

A 24-year-old male, E.B, social and political sciences student at local community college, in his last academic year, who belonging to middle socioeconomic status hailing had presented to psychiatry department of Universitas Sumatera Utara Hospital with complaints about his suffering of excessive fear about COVID-19. These symptoms have been going on for 6 months and getting worse within the last month. Actually, he was living with his sister family in Medan, as his parents live in a different region, Binjai. They usually routinely visit him once a month.

He began experiencing severe heart palpitations, flushing, and fear of fainting and losing control, when hear that his parents RT-PCR result test is confirmed COVID-19 in April 2020, however, his parents did not experience many symptoms clinical features of COVID-19 infection. He never wants to meet his parents since that. He also started to buy a lot of hand sanitizer, masks, face shields, and supplements then doing an excessive self-quarantine in his room. At the time of the intake, E.B was in his final examinations which he wanted to finish successfully, he was afraid that if he were infected by COVID-19, he would get very sick and die, so that all his graduation plans would fail. In addition, in dreaded circumstances, he reported severe chest pain and muscle tension. His fear of these symptoms intensified and led him to escape certain circumstances that made his daily life difficult. When reading and watching all of the COVID19 news on TV or social media, he also encountered similar symptoms. E.B claimed that he had no previous therapy and/or prescription for psychological or medical treatment, and in the 6 months, he had first encountered this problem. He did not disclose any family history of problems with mental or psychological conditions or drug abuse.

$\mathrm{He}$ was the youngest and second child. $\mathrm{He}$ said that he was satisfied when we asked about his childhood and did not report any stressful events. He mentioned a close relationship with both his parents, but since junior high school, they have not been in the same home. During interview session, our patient stated that his sleeps were deprivating at night, feels anxious and slightly fatigue, as well as has difficulty of concentrating throughout the past 6 months and also noted that the symptoms were aggravated in the recent 1 month. Particularly during this pandemic, E.B admitted of becoming more anxious. General physical examination, neurological status, and his vitals were all measured to be within normal limits. Based on psychiatric interview, we observed that generally he presented as reasonably well-groomed, slightly fatigued, shy, and anxious with normal psychomotor activities. His speech was a bit slow and he seemed too easy in understanding questions. He also presented an appropriate affect and seemed to be in euthymic mood. Delusion, hallucination, and illusion were not found. Thought process was normal, the judgment is normal. We marked that his insight related to his current condition was 4 and also found his short-term memory was also normal. No other significant symptoms of psychopathology were reported. Laboratory parameters, such as blood check and thyroid, were found to be normal.

E.B was diagnosed with specific phobia, situational type, that is, coronaphobia with detailed multiaxial diagnoses as the following: Axis I: Specific phobia, Axis II: Anankastic personality, Axis III: None, Axis IV: Environment, and Axis V: GAF 60-51.

\section{Discussion}

A clinical diagnosis of phobia according to the $11^{\text {th }}$ Edition of the International Classification of Diseases (ICD-11) should be taken into account when there is a pronounced and excessive fear or anxiety that has regularly arisen when exposed to one or more specific objects or situations not included in agoraphobia or social phobia, or when such objects or situations are markedly avoided. The patient experiences symptoms of anxiety at some stage after the onset of the condition with substantial emotional distress because of the symptoms or avoidance, and recognizes them as severe or irrational. The symptoms are limited to or when thinking about the scenario being feared [7]

We diagnosed the patient according to ICD-11 and DSM-5, as shown in Table 2.

According to case report above, after complete psychiatric anamnesis, clinical interview, and examination of mental status and referring to the diagnostic criteria shown in Tables 1 and 2, it was determined thatE.Bwas diagnosed with specificphobia, situational type, that is, coronaphobia [7], [8]. We give psychoeducation to him, recognizing diagnosis,

Table 1: A comparative analysis of phobias in DSM-5 with coronaphobia [6], [7]

\begin{tabular}{|c|c|c|}
\hline $\begin{array}{l}\text { Domains } \\
\text { feared stimuli }\end{array}$ & Specific phobia & Coronaphobia (as proposed) \\
\hline Feared stimuli & $\begin{array}{l}\text { Fear about a specific object or } \\
\text { situation (e.g., flying, heights } \\
\text { animals, etc.) }\end{array}$ & $\begin{array}{l}\text { Fear of contracting SARS-CoV-2 } \\
\text { and/or dying of it and sociopersonal- } \\
\text { occupational loss }\end{array}$ \\
\hline $\begin{array}{l}\text { Physiological } \\
\text { response }\end{array}$ & $\begin{array}{l}\text { Palpitations, sweating, trembling, } \\
\text { trouble breathing, dry mouth }\end{array}$ & $\begin{array}{l}\text { Rapid heart rate, trouble breathing, } \\
\text { sweating, sleep disturbances/ } \\
\text { deprivation }\end{array}$ \\
\hline Cognition & $\begin{array}{l}\text { The snake is venomous, it will } \\
\text { kill me! }\end{array}$ & $\begin{array}{l}\text { If I get coronavirus disease, I will die, } \\
\text { lose job, infect others! }\end{array}$ \\
\hline $\begin{array}{l}\text { Behavioral } \\
\text { manifestations }\end{array}$ & $\begin{array}{l}\text { Active avoidance of object or } \\
\text { situation; freezing behavior; } \\
\text { clinging to support (in children) }\end{array}$ & $\begin{array}{l}\text { Active avoidance of public places, } \\
\text { transportation, objects and/or people; } \\
\text { reassurance of not having illness; } \\
\text { safety-seeking behavior to prevent } \\
\text { infection. }\end{array}$ \\
\hline $\begin{array}{l}\text { Intensity of } \\
\text { fear }\end{array}$ & Out of realistic proportion & Out of realistic proportion \\
\hline
\end{tabular}


Table 2: ICD-11 and DSM 5 criteria for classification of phobia [7], [8]

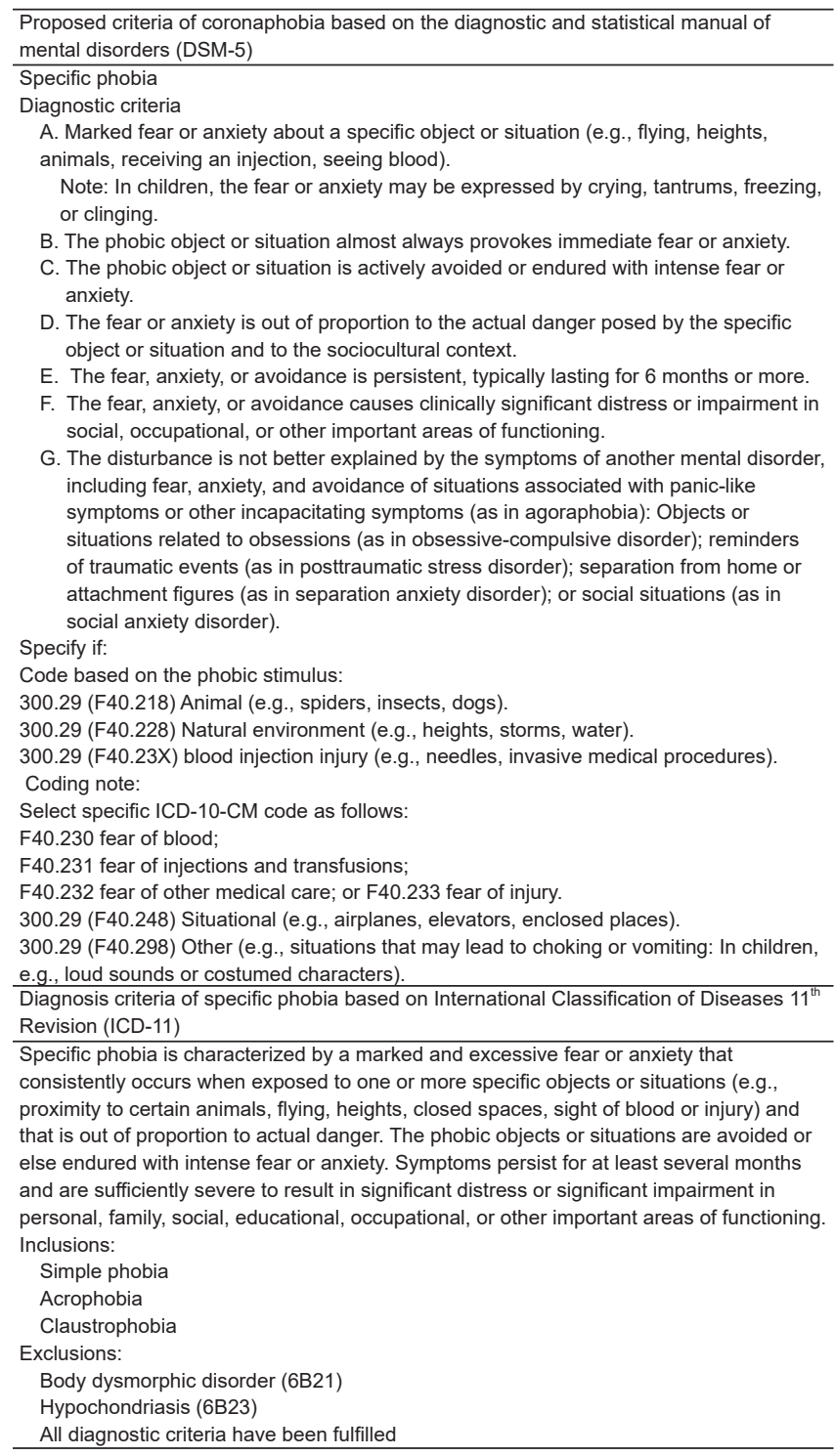

describing the process of learning fear and how it was sustained. Therapy concentrated on giving him potential reasons to challenge his doubts, patterns of avoidance, and efforts were made to replace it with more adaptive values and answers. He has been given homework to do things that he likes, such as reading books, singing, and cycling [8], [9], [10].

Overall, these cases had unique characteristics, we believe that further studies are necessary to completely understand this particular disorder and be able to address it in the future.

\section{Conclusion}

We give psychoeducation to him, recognizing the diagnosis, describing the process of learning fear and how it was sustained. Therapy concentrated on giving him potential reasons to challenge his doubts, patterns of avoidance, and efforts were made to replace it with more adaptive values and answers.

\section{References}

1. World Health Organization. Coronavirus Disease (COVID-19) Situation Dashboard. Geneva: World Health Organization; 2020. Available from: https://www.experience.arcgis.com/ experience/685d0ace521648f8a5beeeee1b9125cd. [Last accessed on 2020 Nov 15].

2. Zu ZY, Jiang MD, Xu PP, Chen W, Ni QQ. Coronavirus disease 2019 (COVID-19): A perspective from China. Radiology. 2020;296(2):E15-25 PMid:32083985

3. Liu S, Yang L, Zhang C, Xiang YT, Liu Z, Hu S, et al. Online mental health services in China during the COVID-19 outbreak. Lancet Psychiatry. 2020;7(4):e17-8. https://doi.org/10.1016/ s2215-0366(20)30077-8 PMid:32085841

4. Asmundson GJG, Taylor S. Coronaphobia: Fear and the 2019nCoV outbreak J Anxiety Disord. 2020;70:102196. https://doi. org/10.1016/j.janxdis.2020.102196 PMid:32078967

5. Coelho $\mathrm{CM}$, Purkis $\mathrm{H}$. The origins of specific phobias: Influential theories and current perspectives. Rev Gener Psychol. 2009;13(4):335-48. https://doi.org/10.1037/a0017759

6. Arora A, Jha AK, Alat P, Das SS. Understanding coronaphobia Asian J Psychiatr. 2020;54:102384. https://doi.org/10.1016/j. ajp.2020.102384 PMid:33271693

7. American Psychiatric Association. Diagnostic and Statistical Manual of Mental Disorders. $5^{\text {th }}$ ed. Philadelphia, PA: American Psychiatric Association; 2013. p. 197. https://doi.org/10.1176/ appi.books.9780890425596

8. World Health Organization. ICD-11 Version: 2011. Phobic Anxiety Disorders; 2011. Available from: http://www.apps.who. int/classifications/icd10/browse/2010/en\#/f40. [Last accesed on 2020 May 07].

9. Pakpour AH, Griffiths MD, Lin CY. Assessing psychological response to the COVID-19: The fear of COVID-19 scale and the COVID stress scales. Int J Ment Health Addict. 2020:1-4. https:// doi.org/10.1007/s11469-020-00334-9

10. Antony MM, Barlow DH. Social and specific phobias. In: Tasman A, Kay J, Lieberman JA, editors. Psychiatry. Philadelphia, PA: WB Saunders; 1997. 